\title{
Christen-Afrikanerperspektief op die Tweede Vryheidsoorlog
}

\author{
Bouke Spoelstra \\ PRETORIA
}

\begin{abstract}
A Christian Afrikaner perspective on the Second Liberation War

Many historical sources testify to the strong religious view of life characteristic of Afrikaners in the previous century. During the mentioned period British colonialism (imperialism) was motivated by the belief in the absolute paramouncy of the British state. The British therefore had little if any sympathy with the rights of any set of people when the interests of the Empire were at stake. Even the epithet "Boer" testifies to the fact that Afrikaners were denied their ethnic identity and were typified as lower-class citizens within the colonial population. On the other hand, during the 19th century, Afrikaners viewed themselves as a separate group of people. Furthermore, to a large extent, they equated themselves politically with the Old Testament Israel. Afrikaners accepted their independence as a gift of God Almighty, an independence accomplished and recognised by the British treaties of 1852 (1881) and 1854. Afrikaners regarded the maintaining of this independence as their religious and moral obligation. The outcome of the War, however, secularised Afrikaner politics and during the 20th century the emphasis in the New South Africa shifted from the idea of people ("volk") to that of racial identity in an artificially unified state.
\end{abstract}

\section{Inleiding}

Hoe langer jy terugkyk in die geskiedenis hoe verder gaan jy die toekoms in (Churchill in McCord, 1952:34). Die sin van die Tweede Vryheidsoorlog word deur Coetzee (1999:20) soos volg gesien: "Oorlog is sinoniem met pyn, lyding en hartseer ... Maar die oorlog is van ons, ons geskiedenis en ons karakter". Onwillekeurig ontstaan die vraag of oorlog deel is van Christen-Afrikaners se psige? Emily Hobhouse (1943:xii) byvoorbeeld sê dat "alle oorlog barbaars is" en dat arbitrasie die verskille tussen beskaafde regerings moet besleg. Ook kan gevra 
word of dit barbaars is om jouself te verdedig. Kan ' $n$ vrou haarself verdedig as haar aanrander sterker is as sy?

Die term Christen-Afrikaner is wyd. Kategorieë Afrikaners kan in die oorlog onderskei word as bittereinders, krygsgevangenes, saamlopers, lafaards, verraaiers, Scouts, "hensoppers" en "joiners" (vgl. bv. Coetzee, 1981). In hierdie artikel word oorsigtelik toegespits op die perspektief van "Boere"-leiers, bittereinders, krygsgevangenes, Kaapse "rebelle", vroue en kinders wat hulle vryheid 32 maande lank verdedig het en die bewondering van die beskaafde Westerse wêreld, selfs van die pasifis Tolstoy (vgl. Kandyba-Foxcroft, 1981) afgedwing het.

Afrikaner-volksbewustheid was in 1899 nog jonk. Baie het aanvaar dat Brittanje se mag die reg bepaal en dat dit sinloos was om duur offers vir onafhanklikheid te bring. Selfs 'n eertydse veggeneraal, Piet de Wet, 'n broer van genl. De Wet, het in Lindley mans en vroue probeer oortuig om oor te gee omdat die mag van Brittanje - volgens hom - getoon het dat God dit so wou (Kestell, s.j:181 e.v; Pakenham, 1979:568). Genl. De Wet (1902:74) stel ook hierdie tipe Afrikaner hulle hulle onafhanklikheid gekos het. "The fact that a fifth of the fighting Afrikaners at the end of the war fought on the side of the British was a secret that has remained hidden till today" (Pakenham, 1979:571). Die Oorlog het 'n diep kloof tussen joiners en bittereinders geslaan (Truter, 1997:71) sodat joiners na die oorlog selfs eie gemeentes moes stig (Van der Watt, 1977:31 e.v.).

Bronne oor die tema - soos in die titel aangedui - is skaars. Uitsprake van verantwoordelike leiers kan egter veralgemeen word omdat hulle as eenvoudige en tipiese Boere-figure sê wat in die gemoed van die volk geleef het. So ook haal objektiewe historiograwe bronne aan en gee sodoende menings weer wat in omloop was. Pres. Paul Kruger hoor byvoorbeeld by elke presidentsverkiesing in die "stem" (verkiesing) van die volk die "stem" van God (Du Plessis, 1952:117). Hy gebruik hierdie siening na analogie van die eerste vraag aan 'n kerklike opsiener by sy bevestiging. Hy aanvaar dat die Here hom deur die verkiesing (die stem) van die volk roep en stel onomwonne dat hy "op staatkundige gebied die ewige beginsels van Gods Woord" bely; ook dat hy weet die volk kies hom op grond van sy "Christelike beginsels" (Du Plessis, 1952:21, 24, 36) wat hulle ook onderskryf. Hy is dus aan God verantwoordelik en nie aan 'n volk wat sy "stem" in 'n kongres formuleer nie. Die volk praat deur voormanne (Du Plessis, 1952:41 e.v). Kruger se perspektiewe in sy gepubliseerde manifeste, intreeredes en toesprake bepaal grootliks die aanloop tot die Oorlog (vgl. Pretorius, 1991:64; De Wet, 1902:82).

Die naam Anglo-Boereoorlog of Boer War (Pakenham, 1979) is egter onvanpas. Die Britte het Christen-Afrikaners "Boers" genoem om 
daarmee te ontken dat hulle met 'n Afrikanervolk te doen het. Hulle wou met dié benaming 'n boerestand binne 'n Britse koloniale bevolking voorstel. Standbewuste Britte moes glo dat Brittanje die regte van medeEngelse en "natives" teen 'n agterlike klas "peasants" of "boors" verdedig (McCord, 1952:25 e.v, 38, 42; Pakenham, 1979:36-53; Fowler, 1944: 122). Die meeste Afrikaners was destyds boere, maar hulle het hulleself toe al "Afrikaners" genoem - selfs "koloniale Afrikaners" (Reitz, 1939:1, 20, 23, 56 e.v; Kestell, s.j:3, 14, 24, ens.) en later ook "ChristenAfrikaner" (Fensham, 1984). Die minagting wat vir "Boere" gekweek is, het Engelse troepe veral uitgehaal op Afrikaner-vroue en -kinders wie se mans geveg het (vgl. Kestell, s.j:200-204; Hobhouse, 1943; Van Niekerk, 1998).

In hierdie artikel let ons kortliks op die Britse politieke perspektief op Afrikaners in die 19de eeu, daarna op die geloofsperspektief waarmee Christen-Afrikaners die Engelse kolonialisme weerstaan en die Tweede Vryheidsoorlog aandurf. In retrospeksie word gekyk na die wyse waarop die Oorlog enkele perspektiewe onder Afrikaners vir die 20ste eeu gevorm het.

\section{2. 'n Perspektief van Britse kolonialisme op die oorlog}

\subsection{Britse vertrekpunt in die absolute (paramount) staat}

Christen-pasifiste het in reaksie op nasionaal-sosialisme "oordrewe nasionalisme" as die oorsaak vir oorloë geblameer en die idee ontwikkel dat 'n "wêreldsamelewing" oorloë kan uitskakel (Van Wyk, 1984:151 e.v, 157 e.v). As nasionalisme die Afrikaners tot oorlog beweeg het, moes hulle die Britse gesag oor die Kaapkolonie aangeval het. Pres. M.T. Steyn het die Britse propaganda dat die Republieke die oorlog met 'n ultimatum begin het, meesterlik weerlê met die feite hoe Brittanje sy magte op die republikeinse grense saamgetrek het (Bredell \& Grobler, 1947:162 e.v). McCord (1952:5-7, 24) stel dat Britse propaganda "demonstrate[s] ignorance, malice and vicious anti-South African racialism" want "Chamberlain and Milner brought war to South Africa, and Chamberlain believed that they had 'once and for all' made South Africa British". Milner weier op 21 Januarie 1901 (en huiwer in Mei 1902) om oor vrede te onderhandel en sê: "The Boers must be completely beaten - if only because that is the sole means of absorbing and ultimately getting rid of them as a separate, exclusive class" (vgl. McCord, 1952:25; Pakenham, 1979:562). Britse universalisme en visie op een Britse Ryk (imperialisme) wou Afrikanerpartikularisme (onafhanklikheid, nasionalisme) vernietig. 
Nasionale state en kerke het in 1648 in Europa die ou Romeinse idee van een ryk en een kerk opgebreek. Toe "nuwe wêrelde" ontdek is, het Europese state gekompeteer om elkeen self 'n nasionale koloniale ryk (empire) op te bou. Pakenham (1991:xvi e.v.) beweer dat die motiewe vir die scramble for Africa omstreeks 1873 moeilik bepaal kan word. Dit hang egter saam met "sendeling" David Livingstone se "3 C's':

Commerce, Christianity and Civilisation, a triple alliance of Mammon, God and social progress ... And it was in Protestant Britain where God and Mammon seemed made for each other ... There was a fourth ' $c$ ' - conquest - and it gradually predominated ... Europe had imposed its will on Africa at the point of a gun" (Pakenham, 1991:xvi e.v.).

Mag was reg en elke Europese volk het homself met beskawing en Christendom geïdentifiseer (vgl. Spoelstra, 1972).

Brittanje het sy "supremacy, preponderance, paramountcy" (McCord, 1952:84, 94 e.v.) wêreldwyd gevestig. "Hence the mercantilist ideal of the powerful state was generally not that it should be wealthy, but that it should be wealthier than any other state" (Knorr, 1968:17). Imperialiste het gedink in terme van die "strength, security and glory of Britain". Die ontdekking van diamante in die Vrystaat en goud in Transvaal het imperialiste soos Rhodes, Beit, Milner en Chamberlain "in accord with a preconceived scheme" laat glo dat "intelligence and power of the ruler" die reg bepaal (Knorr, 1968:7, 12, 24; Pakenham, 1979:30, 54 e.v.). "Victorian imperialism, which was essentially a militant and messianic capitalism" (De Klerk, 1988:208) het van Brittanje se verdrae met "Boere" niks gedink nie (vgl. Bosman, s.j:243; Breytenbach, 1949:1-44). Imperialiste was blind vir 'n menslike waarheid wat die Britse ekonoom, G.F. Schumacher (1973), beskryf in Small is Beautiful; a Study of Economics as if People mattered. Hoewel Duitsland, Denemarke, Holland en België administratief en ekonomies beter as diverse regerings kon bestuur, sou so 'n eenheid tegelyk menslike en kulturele waardes noodlottig tref.

\subsection{Britse vyandskap teen Afrikaners as Fremdkörper in hulle koloniale strewe}

Britse amptenare en geestelikes het vanuit 'n "genuine marriage of Church and State" (Warren, 1967:12 e.v.) met die anneksasie van die Kaap in 1806 Afrikaners as 'n verlengstuk van hulle Hollandse koloniale konkurrent beskou (Froude in McCord, 1952:37). Sendelinge en Anglikaanse geestelikes het met "bias, prejudice, antipathy and hostility" en "malignent falsehood" die Afrikaners verteken (McCord, 1952:38 e.v., 43 e.v., 65, 142). Die Engelse het tot in die Kaap met slawe handel gedryf, 
maar toe antipatie teen slawerny groei, het hulle die "primitiewe Boere" van slawerny beskuldig (Warren, 1967:76 e.v.; Neil, 1966:54, 277). Die Uitlander-League het die deuntjie nog tot kort voor die Oorlog in Transvaal gespeel (Pakenham, 1979:51 e.v.)

Omdat Afrikaners van Europese herkoms was, maar nie soos Engelse "gentlemen" gelyk het nie, is hulle verteken as "Boere" en Doppers, "a dirty obstinate race" (Spoelstra, 1963:16-19). Paul Kruger is deur Rhodes beskryf as 'n "verdomde ou Dopper" (Kruger, 1963:225; vgl. Kruger, 1961:118, 124, 128 e.v.) of as "stupid and dirty Dutch" (Reitz, 1939:53; Froude in McCord, 1952:37, 109). Selfs Pakenham (1979:36 e.v., 55) meet Kruger nog aan sy uiterlike. Rondom Kruger is 'n "Dopperlegend" (Nathan, 1944:92) geskep. Die Britse publiek moes 'n laer sosiale klas in die bevolking sien - en nie 'n jong Afrikaanse volk nie - 'n volk wat ten spyte van hulle minder gekultiveerde en nie-Engelse voorkoms hulle eie republieke binne 'n kort tyd merkwaardig ordelik gefloteer het nie.

Die Britte was as eilanders hooghartig. Almal wat nie Brits was nie, "were in a state of primitive savagery" (Warren, 1967:87). 'n Anglikaanse predikant praat in 1898 van die "semi-civilised Dutch Boer" as "degenerate descendants of the Dutch", al sluit die stamboom van die Afrikaners 'n goeie persentasie Engelse in (McCord, 1952:16-21; De Klerk, 1988:357 nota 71; Truter, 1997:73, 93). 'n Engelse geestelike (Drew), "as usual the political parson ... without truth and Christianity", skryf met blatante laster in The Star 1894 dat Paul Kruger despoties regeer oor 'n "devided, discontented, demoralised State, preyed upon by unscrupulous officials, and threatening ... to go to pieces over its own inherent rottenness" (aangehaal in McCord, 1952:142).

\subsection{Britse staatsidee teenoor die Afrikaner-volksbegrip}

Britse kolonialisme "ought to have no regard to the particular interest of any country or any set of people, the good of the whole is what we ought only to have under our consideration" (Knorr, 1968:131). Imperialisme is nie deur nasionalisme nie, maar deur holistiese "statemaking" bepaal. Strukturele staatseenheid moes kulturele differensiasie verplaas. Sodra die Britse vlag gehys is, hou die verowerde volk op om te wees wat hulle was en word hulle summier Britse onderdane, deel van die "British nation" vir wie Britse kulturele norme voortaan geld. Kitchener hou Australië in 1902 by die vredesonderhandelinge as voorbeeld van "statemaking" voor, waarop pres. Steyn hom daarop wys dat Australië nie soos die Afrikaners 'n vrye volk in onafhanklike republieke was nie. Om hulle vryheid te roof sal 'n grief soos in lerland laat ontstaan (Kestell, s.j:234). Die Britte was behep met die staat, met king and country. Hulle 
praat van "people" (mense), "race" (ras) of "nation" (bevolking) en het nie 'n woord vir "volk" nie (Spoelstra, 1972:159), juis die saak waaroor dit vir Christen-Afrikaners gegaan het.

\subsection{Machiavelliaanse politiek}

Die Britse politiek teen die Republieke volg die lyne van Machiavelli $(+1527)$. Hy het geleer dat die staat absoluut en terwille van homself bestaan en aan geen norme gebonde is wanneer hy homself kan bevoordeel nie (Hogeweg, 1959:531). Brittanje het in ooreenstemming met hierdie uitgangspunt die Voortrekker-Republiek van Natal in 1843 geannekseer en Trans Oranje in 1848. Die onafhanklikheid van Transvaal is egter in 1852 en dié van die OVS in 1854 met verdrae erken, maar daarna weer willekeurig geskend. Lord Carnavon laat Shepstone die "rape of Transvaal" (anneksasie) in 1877 deurvoer. "The treaties and pledges that stood between the matter of honour and decency, meant nothing at all" (McCord, 1952:66; Kruger, 1961:I, 119-200). Biskop Colenso, wat ook die Zoeloes se reg op 'n eie kultuur en politieke selfbeskikking verdedig het, het die "sly underhand way in which the Transvaal had been annexed" veroordeel (Reitz, 1939: 14), maar Brittanje "smashed the whole basis of international life; destroyed the sanctity of treaties, and made international life subject to the desires and ambitions of the strongest" (McCord, 1952:83). Na die ontdekking van goud in 1886 in Transvaal het Rhodes, Chamberlain en Milner die aanslag herhaal. Staatsprokureur Jan Smuts, een van die eerste koloniale Afrikaners wat Kruger in Transvaal aangestel het (Pakenham, 1979:42 e.v.), tipeer die 19de eeu op grond van die Britse optrede teen Afrikaners as Een eeuw van onrecht (Reitz, 1939; Oost, 1956?:21).

\subsection{Die opmars teen die Republieke}

Engeland het na die Eerste Vryheidsoorlog in 1881 as "paramount power" 'n vae "soesereiniteit" oor Transvaal behou. Pres. Kruger het geslaag om dit in 1884 op te hef. Brittanje moes slegs geken word voordat ooreenkomste met buitelandse moondhede aangegaan word. Die "skilpad" (imperialisme) het egter weer met mening begin loop toe Rhodes se Chartered Company Rhodesië in 1892 geannekseer het sodat die idee van 'n Britse Ryk van die Kaap tot aan die Zambesi verwesenlik kon word.

Jameson het as pion van Rhodes Transvaal aan die einde van 1895 gewapend uit die Kaapkolonie binnegeval in die waan dat die "Uitlanders" ook sou rebelleer. Transvaal het die leiers van die "raid" grootmoedig aan die Britse Regering oorgelewer. Van straf het weinig tereg gekom. Die "raid" het Afrikaners egter van die Limpopo tot in die 
Kaapkolonie waar verengelsing ver gevorder het, wakker gemaak en laat besef dat die aanslag ook op hulle volksbestaan gemik is (De Klerk, 1988:74, 90 e.v.). Andersyds het Brittanje in 1897 'n verbete imperialis, Alfred Milner, as Hoë Kommissaris na Suid-Afrika gestuur om Jameson se brouwerk reg te maak en Transvaal met sy goud vir Brittanje te wen (Pakenham, 1979:21 e.v., 28 e.v., 57 e.v.; 1991:563). Die Eerste Minister van die Kaap, John X. Merriman, Olive Schreiner en haar man, J.H. Hofmeyr en baie ander in die Kaapkolonie het die imperialistiese komplot teen Afrikanerregte verfoei en gesien hoe jingo's op oorlog afstuur. Hulle was in die oë van Milner "mugwumps".

Die twee Republieke het in 1897 'n verdrag gesluit om mekaar te help as een van hulle militêr bedreig sou word. Hoewel in die huis van pres. Steyn voor die oorlog by voorkeur Engels gepraat is, het juis hy tydens die Oorlog alles feil gehad vir Afrikaner-onafhanklikheid in die twee republieke. Toe die fut van die Transvalers haas uit was, het hy so siek soos hy was die vaandel vir onafhanklikheid tot Mei 1902 by Vereeniging gedra. Na die oorlog het hy en sy eggenote hulle vir Afrikaans en Afrikaanse skole beywer (Kruger, 1963:143-173; Truter, 1997:38 e.v.)

Milner het in stryd met die Londonse Konvensie van 1884 griewe van die Uitlander-League help orkestreer en wou eintlik nie daaroor onderhandel nie. Hy het gemeen dat Brittanje as "paramount power" in huishoudelike sake van Transvaal moes inmeng, alhoewel 'n gesaghebbende meerderheid "uitlanders" steeds met die Transvaalse administrasie tevrede was. Milner het Transvaal se toegewings en aandrang op onpartydige arbitrasie gevolglik bly verwerp. Hy skryf op 22 April 1899:

I know perfectly well that if the Home Government took the strong line about the internal affairs of the Transvaal, which in my opinion they ought to take, there would be a general howl from the Dutch and the 'mugwumps' ... I can't see why we should allow our policy to be influenced by them ... (McCord, 1952:136, vgl. 111-155; Kruger, 1963:16-140).

Hy was gevolglik in sy noppies toe die Britse kabinet op 9 Mei 1899 die groen lig gee om in Transvaal in te meng (Pakenham, 1979:59 e.v.)

Net voordat pres. Kruger hom oor "uitlandergriewe" op 28 Mei 1899 by pres. Steyn in Bloemfontein sou ontmoet, skryf Milner dat elke "mugwump" moet weet "before the bomb bursts ... that Britain means to have her way this time" (McCord, 1952:136). Die "skilpad" het met mening geloop. "It was the ambition ... from Sir George Grey in 1856 to Lord Milner to bring the whole of South Africa under the British flag" (McCord, 1952: 94). Dit laat die gryse president Kruger op 31 Mei 1899 met trane in sy oë vir Milner in Bloemfontein sê: "Dit is nie stemreg wat julle wil hê 
nie, dis my land! My land!" (Breytenbach, 1949:44). Die oorlog wat daarop gevolg het, noem Pakenham (1991:557) met reg "Milner's War".

\section{Perspektief uit die Eerste op die Tweede Vryheidsoorlog}

\subsection{Geboorte van Afrikaner-onafhanklikheidsbesef}

Los groepe Afrikaners het in die Groot Trek die vyandige Britse bestuur in die Kaapkolonie ontvlug. Hulle het verskillende trekowerhede op die kommandostelsel geskoei totdat hulle 'n volksraad vir die Republiek Natal kon daargestel. Hulle het geglo dat God hulle soos Israel van ouds deur leiers regeer (Du Plessis 1952:13). Hulle het 'n vae volksbesef gekoester op sterkte van 'n gemeenskaplike godsdiens, taal en geskiedenis. Hulle geskiedenis het hulle geleer dat God hulle in sy voorsienigheid as volk soos Israel na 'n "beloofde land" (onafhanklikheid) gelei het. Toe die president en volksraad gekies is, het die volk hulle eie staat (republiek) gevorm om te behou wat God gegee het. Daarteenoor het Britse imperialisme 'n staat met geweld afgedwing en verwag dat die bevolking (onderdane) dit moet aanvaar. In hierdie geval "het die staat 'n volk" gemaak (Van der Walt, 1969:15). Vir Christen-Afrikaners (tot selfs in die Kaapkolonie) het dit primêr om die volk gegaan en vir Brittanje primêr om die staat. Dié twee perspektiewe kom in 1899 gewapend teenoor mekaar te staan.

Toe Brittanje Natal in 1843 annekseer, sê Johanna Smit namens 'n vroue-deputasie aan die Britse agent dat

... hulle hulle nooit aan die Britse gesag sou onderwerp nie; en waar verset tevergeefs mag wees, sou hulle liewer kaalvoet oor die Drakensberge teruggaan na vryheid as om onder Britse bestuur in Natal te bly ... Hul wagwoord was: Die vryheid of die dood (Bosman, s.j.:229).

Brittanje erken die onafhanklikheid van die emigrante in Transvaal met die Sandrivier Konvensie in Januarie 1852 en van die OVS met die Bloemfontein Konvensie van 1854, al het ds. Murray en Engelse sakemanne daarteen geprotesteeer (Spoelstra, 1963:148 e.v.). Juis die Vrystaters onder pres. Steyn en genl. De Wet wou die Oorlog in 1902 voortsit tensy hulle onafhanklikheid in een of ander vorm erken word (Kestell, s.j:253).

In die vorige eeu het Christen-Afrikaners se sin vir onafhanklikheid ook hulle visie op die plurale swart volkgroepe bepaal. Die visie het radikaal verskil van die latere rasse-"apartheid" binne 'n eenheidstaat wat binne die grondwet van die Unie van Suid-Afrika in 1910 ontplooi en sedert 1948 verder gekodifiseer is. Paul Kruger sê hulle 
... reël was om van niemand iets weg te neem nie, selfs nie van die swak stamme in die Vrystaat nie ... God het dit belet ... Wat ons van die nasies wou hê, moes ons met vrede en vriendskap probeer om van hulle te verkry deur middel van onderhandeling en niks het ons geweldadiglik geneem nie (Du Plessis, 1952:102).

Kruger verwys na "Makatese" wat tydens die Mefecane uit vrees vir die Zoeloes en Matabele weggekruip en daarna tussen Afrikaners kom woon het. Hy beskou die "talryke kafferstamme onder en rondom ons" as selfstandige eenhede. Tog is sy denke ook al verward wanneer hy ook 'n vorm van voogdyskap veronderstel om "barbaarsheid deur regverdigheid en beskawing" in toom te hou (Du Plessis, 1952:24). In die Oorlog het baie swartes vlugtende Afrikanervroue gehelp of as agterryers die Boeremagte gedien. Tog het Afrikaners - anders as die Engelse - die swartes nie bewapen of deel van die oorlogvoerende partye gemaak nie. Die Britte het egter die selfregering van die Xhosas en die Zoeloedinastie tussen 1877 en 1879 vernietig, hulle gekoloniseer en as Britse onderdane teen die Afrikaners in die oorlog bewapen. Die Britse oormag van wit en swart dwing die oorgawe in 1902 af (Kestell, s.j:277).

\subsection{Perspektief vanuit die Eerste Vryheidsoorlog op God se voorsienigheid}

Die Britse politiek wat tot die Eerste Vryheidsoorlog lei, is elders volledig beskrywe (Krüger, 1961:I, 100-200; Bosman, 1961:297, 300 e.v.) Na die anneksasie van Transvaal in 1877 het Paul Kruger steeds as visepresident namens die volk die Britse Regering probeer oortuig dat "waarheid, geregtigheid en wettigheid" vereis dat die anneksasie ongedaan gemaak moes word. Hy het geslaag om burgers "wat moeg was van plaery, wanvoorstellings en daardie minagtende neerbuigendheid wat met die onderdrukking van byna drie jaar gepaard gegaan het", kalm te hou. Dit het die volk se liefde vir formele, wetlike korrektheid en afkeer van geweld geillustreer (Krüger, 1961:I, 184 e.v.). Toe hulle in 1881 op haas 'n ongelooflike manier die magtige Engeland met die wapen dwing om hulle vryheid te herstel, kon hulle daarin "niks anders sien nie as die hand van die Almagtige God, wat hulle soos Israel van ouds ... na die beloofde land gelei het. ... God openbaar Hom immers nie slegs in die Skrif nie maar ook in die geskiedenis ..." (D.W. Kruger in Du Plessis, 1952:11 e.v.)

Die Engelse geskiedskrywer Froude kon nie glo dat die Vrystaters die God van geregtigheid "as 'n werklikheid in hulle politiek beskou" nie (Reitz, 1939:12). Op 16 Desember 1880 te Paardekraal, waar ds. N.J. van Warmeloo van die Ned. Herv. Kerk die enigste predikant onder ongeveer 8000 burgers was, het Kruger verklaar: "Ek staan hier voor u 
... geroep deur die volk; in die stem van die volk het ek die stem van God gehoor, die koning van die volke". Kruger se woorde impliseer onder andere die volgende: God roep hom deur die volk om hulle onafhanklikheid te bewaar. Al is die volk swak, God is 'n regverdige God en hulle saak regverdig. Hy bid dat die Here hulle sal seën en verwag van elke burger om "tot die laaste man" sy lewe vir die "onafhanklikheid van ons dierbare vaderland" op te offer (Kruger, 1961:I, 203 e.v.)

Hierdie geloofsperspektief op 'n saak wat op die oog af verlore was, is deur vier veldslae bevestig. Die laaste veldslag was op 27 Februarie 1881 te Majuba, waar die Britse aanvoerder Colley gesneuwel het. Kruger het 'n dag van verootmoediging uitgeroep en bely:

Ons roem nie in die krag van mense nie. ... Dit is die God van ons vadere tot wie ons nou vier jaar lank om redding gebid en gesmeek het. Hy het groot dinge aan ons gedoen en ons gebede verhoor. Hou vol tot die einde toe ... Vertrou op Hom.

Kruger se biograaf sê ook die volgende:

Hoe weinig het Colley en Kruger besef dat hulle in hul handelinge wel die drade gehou en getrek het, maar dat 'n mag buite en groter as hulle die tapyt van die geskiedenis geweef het. Die drama wat in daardie tyd afgespeel is, het as agtergrond die onvermydelikheid en onverbiddelikheid van 'n Griekse tragedie sodat oorsaak en gevolg 'n byna demoniese ketting gevorm het (Kruger, 1961 l:228).

Ook pres. Steyn het sy onvermydelike plig tot selfverdediging met "' $n$ kenmerkende oorheersende Godsvertroue" aanvaar (Tienie van Schoor, WoonBurger 18.10.99:iii). Die perspektief op die wil en voorsienigheid van God is dominant voor en tydens die Tweede Vryheidsoorlog.

\subsection{Geloofsperspektief op onafhanklikheid}

Die geloofsperspektief kom 'n lang pad. Joachim Prinsloo, voorsitter van die Natalse Volksraad skryf op 21 Februarie 1842 aan die Kaapse Goewerneur:

Ons weet dat daar 'n God in die hemel is en wat die mag het en gewillig is om die swakkes teen hul onderdrukkers te beskerm. Op Hom vertrou ons en op die regverdigheid van ons saak. Indien dit sy wil is dat ons, ons vrouens en kinders totaal vernietig moet word, sal ons ons nederig aan sy wil onderwerp. Ons wil die mag van Engeland nie uitdaag nie; maar ons kan nie toelaat dat mag oor reg sal seëvier sonder dat ons dit met al die kragte wat ons besit, bestry het nie (Reitz, 1939:8). 
Vanuit die gereformeerde godsdiens het Paul Kruger in sy politieke toesprake van 1881 tot 1899 die volk gedurig met die geskiedenis van die Groot Trek en Eerste Vryheidsoorlog gekonfronteer om te bewys dat God reg lief het en onreg straf. In huis, skool en kerk het plattelandse Christen-Afrikaners nie net in die Bybel "skoolgegaan" nie, maar ook in God se openbaring in natuur en geskiedenis (art. 2 NGB; D.W. Krüger in Du Plessis, 1952:12; vgl. toesprake in Du Plessis, 1952:21 e.v., 32, 50 e.v., 56, 102 e.v. ens.). Toe 'n Engelse predikant vir Kruger vra hoe hulle sonder telegraaf of spoorlyn die Engelse magte in 1881 kon verslaan, was sy kinderlike antwoord:

... as ek en die heer Joubert dit moes doen, [sou] dit sleg ... afgeloop het, maar dit was die werk van ons grote Generaal, Jesus Christus, want as ons bevele op 'n plek aangekom het, dan was dit alreeds uitgevoer ... Die geringste heiden en ongelowigste moet erken dat dit Gods hand is wat aan ons ons vryheid teruggegee het (Du Plessis, 1952:106).

Kruger het onafhanklikheid as noodsaaklik beskou om na binne "eendrag en eensgesindheid" en na Bo opregtheid in die verhouding van die "Godsvolk" tot die "troue Verbonds-God" uit te bou. Die neo-Platoniese (Lutherse) skeiding tussen 'n ryk van natuur waar politici werksaam is en 'n ryk van genade waar die "kerk" werksaam is, ken hy nie. Volgens Kruger staan politici en kerklui in die volk in diens van dieselfde God. Kruger sê:

God het hierdie Christelike staat opgerig en 'n Christelike regering wat die kerk buite om sal beskerm ... Staan vas op Gods Woord ... Dit is 'n groot voorreg dat $u$ Regering Christelike onderwys neergelê het ... Ook is dit 'n groot voorreg dat die Regering en Volksraad $u$ taal as taal van die staat aangeneem het. Hou daaraan vas, aan die taal waarin $u$ voorouers ... geworstel en God aanbid ... het. Laat die godsdiens dan nie verwaarloos word nie want dit is die grondslag van kerk en staat (Du Plessis, 1952:72-74, 81; vgl. art. 36 NGB).

In die tyd van die Oorlog was die lewe beskou as 'n eenheid; dieselfde mense (volk) was op onderskeie lewensvlakke kerk en staat. Opmerklik genoeg val Milner onmiddelik na die oorlog juis aan op hierdie eiendomlike van die Afrikaanse volk: taal, kultuur en Christelike onderwys (Pakenham, 1979:575). Die geskiedenis herhaal homself wanneer die Afrikaner in 1994 party-polities die regering aan 'n AfroEngelse ANC oorgee.

Kruger het op 12 Mei 1898 sy vierde ampstermyn as bekommerde staatshoof aanvaar en sê: "God se arm is uitgestrek. Hy tugtig ons ... met droogtes, runderpes, sprinkane, koorssiekte en pokke en dreigende 
oorlog. Die volk dien die wêreld terwyl ons wil hê dat die Here vir ons siel sal sorg ...". Hy stel dit dat God hulle tot inkeer wil bring omdat hy sy volk nie wil verlaat nie (Du Plessis, 1952:45, 51, 60 e.v.). In sy laaste toepraak voor die Eerste en Tweede Volksraad op 7 Mei 1900 verklaar hy "dat verootmoediging voor God uiteindelik tot oorwinning en genade sal lei" (Pretorius, 1991:190). As direkte staatshoof roep hy die volk buite die kerke om op tot dae van verootmoediging en gebed. Sodanige verootmoedigingsgeleenthede was iets wat die volk nie geken het nie en Kruger self uit artikel 66 van die Dordtse Kerkorde van 1619 geleer het. Onder die besef van sonde by die volk het Kruger dikwels 'n toespraak onderbreek om eers Psalm 25 vers 2 te laat sing (Du Plessis, 1925:49, 51, 55, 89 e.v., 98-102). "Kruger put his trust in God; that goes without saying. He put less trust in the Mauser. He viewed the war with the deepest foreboding" (Pakenham, 1979:101).

\section{Christen-Afrikanerperspektief in die Oorlog}

\subsection{Afrikanerperspektief bewaarheid in die stellingfase tot Maart 1900}

Smuts skryf in 1899:

Die Geregtigheid waarop Piet Retief hom beroep het ... en waarop Joachim Prinsloo hom in die Volksraad van Natal beroep het ...die Geregtigheid waaraan die burgers van Transvaal hul saak op Paardekraal in 1880 toevertrou het, bly onveranderlik en soos 'n rots waarteen die golwe van Britse diplomasie uiteenspat (Reitz, 1939: 56).

Klinkende oorwinnings oor die Britse magte op die Natalse en Wesfronte gedurende die eerste halfjaar van die Oorlog het die geloofsperspektief grootliks bewaarheid (vgl. Breytenbach, 1949: 75-114). Die Boereaanvoerders was nie opgelei in krygskuns nie en dissipline het dikwels onder die burgers ontbreek. Sommige kommando's (soos dié van genl. Piet Cronjé) is met vrouelaers belas. Traagheid en versuim het ook onder die Boere voorgekom - 'n aspek wat die Engelse soms die geleentheid gegee het om versterkings in te voer. Ladysmith, Kimberley en Mafeking is sinloos lank beleër. Eiesinnigheid, lafhartigheid, ongemotiveerdheid of verraad het byvoorbeeld Cronje aan die Wesfront en Marthinus Prinsloo in die Oos-Vrystaat teen Maart 1900 met byna 8000 burgers uit 'n totale Boeremag van ongeveer 50000 laat oorgee. Hierdie nederlaag het baie offisiere en burgers laat wapen neerlê. Vir De Wet het God die ontrou van Afrikaners op hierdie wyse gestraf (De Wet, 1902:64, nota 112). 
Omdat min predikante die kommando's vergesel het, het "Boereleiers", offisiere en manskappe die burgers drie jaar lank geestelik versorg en bemoedig. By geleentheid het generaals De la Rey, Beyers en Smuts in Wes-Transvaal gewys op die "wording van die Afrikanervolk" onder God se bestel sodat verraad teen die volk verraad teen God is. Tereg word gesê dat die burger op kommando 'n "noue verweefdheid van godsdiens met nasionalisme" beleef het (Pretorius, 1991:171 e.v., 176 e.v., 179 e.v., 352). Hulle het hul volksbestaan as 'n religieuse gegewe belewe. Pres. Steyn, generaals soos De Wet en baie burgers wou daarom in Mei 1902 nog vir onafhanklikheid voortveg.

\subsection{Die perspektief wat lei tot die guerrillafase}

In die stellingfase van die Oorlog het begaafde aanvoerders soos die legendariese C.R. de Wet die plek geneem van gekose politici wat aanvanklik bevel gevoer en misluk het. Toe die stellings aan die Natalse en Wesfront ineenstort, het die presidente van die Vrystaat en Transvaal, en 'n nuwe geslag generaals moedelose burgers aangevuur om die onafhanklikheid en vryheid van die republieke verder te verdedig. Baie het 'n kort tydjie huis toe gegaan, teruggekom en toe as bewegende guerrillakommando's geveg. Pogings om in 1901 en selfs in Mei 1902 nog vrede te sluit, het gestuit op die Britse eis dat die republieke hulle onafhanklikheid onvoorwaardelik moet prysgee. Die kommando's was gemotiveer deur

... 'n wydverspreide vaderlands- en vryheidsliefde wat allereers op die onafhanklikheid van die Republieke toegespits was ... Tweedens was daar die godsdiensbeskouing van baie burgers - hul geloof dat hulle vir 'n heilige en regverdige saak geveg het en God hulle daarom sou help. Derdens was daar die toenemende vasberadenheid onder die burgers om die stryd voort te sit namate die Britse verskroeide-aarde-beleid om hulle ontplooi en berigte van die lotgevalle van hulle familie in die konsentrasiekampe na hulle deurgesypel het ... Daar kan aanvaar word dat spesifieke redes nie ewe sterk by alle bittereinders aanwesig was nie (Pretorius, 1991:352).

\subsection{Die perspektief van predikante}

Tydens die stellingfase van die Oorlog het 'n groot aantal predikante uit Afrikaanse Kerke, selfs Engelse, Duitse en Roomse geestelikes, die burgers te velde bedien en bemoedig. Die meeste predikante het egter verdwyn toe kommando's in die guerillafase "in lywige, swerwende gemeentes, immer wisselend in samestelling en lidmate-tal" die stryd voortgesit het. 'n Paar "swerwende" NG predikante, byvoorbeeld ds. J.D. Kestell van Harrismith het by die kommando van genl. de Wet gebly en die gryse ds. M.P.A. Coetsee van die Geref. Kerk Belfast het hom 
gevoeg by die kommando's van generaals Ben Viljoen en C.H. Muller. Die meeste het nie geveg nie, maar verpleeg, bemoedig en dienste gehou (Kestell, s.j:284). Ds. Paul H. Roux van Senekal het as veldprediker begin, is vanweë sy bekwaamheid as veggeneraal aangestel, terwyl sommige dit vir 'n predikant as onvanpas beskou het (Moll, 1981: $550)$.

Om die perspektief van predikante op die Oorlog te bepaal sou 'n studie op homself verg. Skynbaar het talle (soos met die Groot Trek) hulle nie enduit geïdentifiseer met die stryd om onafhanklikheid nie (Kestell, s.j: 67). Ander het seker, óf as klerikale stand óf gewoond aan Britse gesag in die Kaapkolonie, die uitslag op die kantlyn afgewag. Ds. J.G. Kuhn doen in 'n ope brief van 28 Junie 1901 'n beroep op NG-predikante om op te tree omdat die Boere-leiers teen "die wil van God" rebelleer (Van Niekerk, 1998:50). Daarby het die reeds genoemde neo-platonisme 'n dualisme tussen staat en kerk veroorsaak. Sommige predikante het hulleself beskou as dienaars van 'n geestelike koninkryk (genade) buite en bo die stryd om Afrikanervolksbelange (natuur), terwyl die eintlike kerk, die burgers te velde as Christen-Afrikanervolk in 'n stryd om lewe en dood gewikkel was.

Die Wes-Europese corpus christianum het pous en keiser, kerk (predikante) en staat (politici), skerp geskei. Die Anglikaanse huwelik tussen staat en kerk soos Suid-Afrika onlangs in die WVK weer ervaar het, was onder Afrikaners onbekend. Gevolglik het predikante en kerke hulle oë vir die barbaarse en misdadige oorlogsmetodes gesluit. Die Britse opposisieleier, Campbell Bannerman, het tydens die slotfase van die Oorlog beweer dat oorlog nie meer die oorlog van ' $n$ beskaafde moondheid is wanneer dit deur barbaarse metodes gevoer word nie. Nogtans het Afrikaanse predikante nie georganiseerd in die Kaapkolonie of in Europa die metodes en gevolge van Britse oorlogvoering teen sagte teikens (Kestell, s.j: 200-204) uitgewys of diakonale hulp vir vroue en kinders georganiseer nie. Eers na die Tweede Wêreldoorlog en die stigting van die Wêreldraad van Kerke het dit mode geword dat kerke en predikante polities en moreel-selektief by uhuru, anti-apartheid- en bevrydingsbewegings teen kolonialisme betrokke raak. Emily Hobhouse (1943:xi e.v) het vrou-alleen probeer om die Britse publiek te oortuig dat die Britte die Haagse Konvensie van 1898 skend. Sy het bykans geen steun van kerke en predikante gekry nie.

\subsection{Godsdienstige perspektiewe tydens die Oorlog}

Tydens 'n viering van Dingaansdag op 16 Desember 1900 te Schimmelkop in Wes-Transvaal verkeer ds. A. Kriel onder "intense besef van die sondigheid van die Afrikanervolk" omdat die staatsfees wat elke 
vyf jaar op 16 Desember by Paardekraal die Eerste Vryheidsoorlog herdenk het, gevier sou word in 'n wêreldse gesindheid en met vermaak. Kriel wou skynbaar Geloftefees soos Charl Celliers as 'n Sabbat vier, 'n idee wat tydgenootlike dokumente van 1838 nie regstreeks bevat nie (Spoelstra, 1982). Die Transvaalse regering en Volksraad van die OVS het 16 Desember in 1894 as 'n vakansiedag maar nie as 'n Sabbat geproklameer nie (Pretorius, 1991:180).

Joernaliste wou burgerkommando's met die 17de-eeuse volksleër van Oliver Cromwell vergelyk omdat daarin dieselfde erns, daaglikse godsdiens en gebede voorgekom het. Afrikaners het egter nie oorlog gevoer omdat hulle hulleself as die uitverkore volk van God beskou het nie. "Hoogstens kan daar ... van 'n roepingsbewustheid gewag gemaak word met enkele toespelings op die Afrikaner as die uitverkore volk van God" wat dikwels tydens "ontwakende nasionalisme" by 'n volk na vore kom (Pretorius, 1991:185). Genl. Smuts tref by kommando's in gebede en godsdiensoefeninge diep erns en toewyding aan.

As the contest has deepened ... and sorrow has followed sorrow until they seemed verily to have arrived in the valley of the dark shadow, this remarkable faith in God and in their destiny has only become stronger ... (aangehaal deur Pretorius, 1991:187).

Die oorlog het baie Afrikaners se godsdiens verdiep en talle offisiere het daartoe bygedra (vgl. Kestell, s.j:43).

'n Mens mag nie die godsdienstige perspektief van Christen-Afrikaners op die oorlog veralgemeen nie. By talle burgers was daar onverskilligheid, kleingeloof, ongeloof, ydelheid, afkeer van God, die Skrif en godsdiens. Daar was ook huigelary, geveinsdheid, dwepery en die misbruik van godsdiens. Tog was die meerderheid oortuig dat hulle vir 'n heilige en regverdige saak stry soos God dit wil. Hulle het geglo dat met die reg aan hulle kant was God aan hulle kant - om te seën of te tug. Toe die Tugela-linie teen Maart 1900 swig, laat Kruger vir Joubert weet dat hulle op God moet vertrou maar hulle moet daarmee saam hulle uiterste plig doen. Toe van genl. Cronjé se manne by Paardeberg wou uitbreek, het hy dit belet omdat hy sy haglike posisie aan die wil van God, in plaas van aan sy eiesinnigheid, toegeskryf het en hy hulp van onder andere De la Rey en De Wet geweier het.

Die oortuiging dat die soewereine God met sy wil oor die lot van elke mens beskik, het sterk in die kommando's geleef. Teenslae in die Oorlog is meermale vertolk as straf op die sonde van die volk en burgers.

Hieruit het die belangrike Christelike perspektief gevloei dat die oorlog met sy smart en verwoesting 'n beproewing van God oor hulle 
gebring het om hulle te louter en so van hulle sonde te verlos en hulle gereed te maak vir die Hemelstaat, vir die oorwinning hiernamaals (Pretorius, 1991:194-202).

\section{5 'n Anti-Britse perspektief by Afrikaners ingebrand}

Die mislukte Jameson-inval in 1895, die aggressiewe imperialisme van Chamberlain en Milner, die laakbare Britse militêre beleid van "verskroeide aarde" en ongevoeligheid vir die lyding van vroue en kinders wie se kos, klere, komberse en eiendom verbrand is, die leuen (Kestell, s.j:271) dat Boere hulle vroue en kinders verwaarloos en die Britte hulle om mensliewende redes in kampe beskerm het, het 'n diep veragting vir die Engelse Regering en "Tommies" by baie ChristenAfrikaners ingebrand (vgl. Van Niekerk, 1998; Kestell, s.j:196, 203).

Hierdie veragting vir die Engelse is ook geïntensiveer deur die volgende: die militêre gebruik van swartes teen vroue en kinders, die wanbestuur in "moordkampe" waar honger, siekte en verwaarlosing 26000 vroue en kinders, groot en klein in bietjie meer as 'n jaar afgemaai het, die "wreedheid van die ongevoelige Britse Parlement" wat elke beswaar teen die Britse optrede weggevee het (Hobhouse, 1943:117-119). Ook die gebruik van minderwaardige Afrikaners as "joiners" teen hulle eie mense toe Brittanje die Boere nie militêr kon verslaan nie. Bittereinders was vasbeslote om nie te ver-Brits nie (McCord, 1952:173), al het baie van hulle na die Oorlog steeds hulle generaals Botha en Smuts gevolg toe hulle "konsiliasie" met die oog op 'n verenigde nasie in Suid-Afrika gepropageer het (Spoelstra, 1953:324 e.v., 350, 363 e.v.). Nogtans was hulle harte nie daarin nie (Kruger 1958:27).

Die Britse regering, Milner, Kitchener en sy offisiere kan gesien word as skuldig aan "blood guilt". Hulle was "war criminals" en "forerunners of Hitler and Goebbles" in "bullying a small state" (McCord, 1952:77, 81 e. v.) en het selfs teenoor krygsgevangenes anders as die Boeremagte opgetree (Kestell, s.j:218). ${ }^{1}$

Namate die Oorlog voortgeduur het en swakkeres "gehensop" het, het kollektiewe vasberadenheid, vaderlandsliefde, nasionalisme en die wil om onafhanklik van Brittanje te bestaan, die guerillakommando's al kragtiger besiel. As gevolg van die "verskroeide-aarde"-beleid waarmee Lord Kitchener die Boere wou vernietig, het baie van hulle niks gehad

$1 \quad$ Volgens moderne internasionale norme behoort Brittanje talle van sy politieke en militêre aanvoerders in die Oorlog van 1899-1902 postuum van hulle titels te stroop weens die skending van die Haagse Konvensie en die "misdaad teen die mensdom" vgl. Martiens van Bart in Bylae tot die Burger 20.11.99:ii. 
om na te verlang of na terug te keer nie. Hulle wou voortveg (Pretorius, 1991:352-358).

\subsection{Perspektief by Christen-Afrikanervroue en -kinders in moord- kampe}

Dolf van Niekerk (1998) sê dat veral vroue die pyn en lyding van die oorlog in Engelse konsentrasiekampe gedra het. "Ironies, in nie een van die briewe wat ek gelees het, was die vroue in opstand teen die stryd nie. Ja, hulle het erken dat hulle swaarkry, hulle kinders en naasbestaandes sterf, maar nie een wou ophou veg vir dit wat aan hulle behoort nie" (Coetzee, 1999:23). Die Afrikanervrou van weleer was sterk ingestel op en miskien beperk tot haar man, kinders, huis, kerk en volk. Sy het die Oorlog lydsaam as offer aanvaar om die eie te behou. Ook in hedendaagse fiksie word die rol van vroue in die Oorlog beklemtoon. Van die kortverhaalbundel Boereoorlogstories sê Jeanette Ferreira byvoorbeeld:

Wat veral opvallend in Boereoorlogstories is, is die belangrike rol wat vroue in die verhale speel. Die vroue wat uitgebeeld word, is nie patetiese mense met uitgeholde wange en ingesakte oë in die konsentrasiekampe nie. Ek dink baie vroue was die dryfkrag agter die mans se waagmoed (Jeanette Ferreira in Coetzee, 1999:21).

Die ontsettende lyding van vroue en kinders het ook mans laat "hensop" en uiteindelik in Mei 1902 oorgawe afgedwing (Pretorius, 1991:329, 332, 364 e.v.)

\subsection{Christen-Afrikanerperspektief op beskaafde Europa}

Toe die onderhandelinge met Milner op 'n dooiepunt bly uitloop, die onafhanklikheid van die Republieke in stryd met volkereg bedreig is en op oorlog afstuur, het die Transvaalse regering op 9 Junie 1899 by Milner aangedring om die geskil aan arbitrasie deur een verteenwoordiger van elke party en 'n onafhanklike arbiter (moontlik uit Europa) te onderwerp. Milner het egter oorlog en nie 'n skikking verlang nie. Selfs toe Brittanje sy troepemagte weerskante van die twee Republieke saamtrek, het die Republieke op 9 Oktober 1899 in die ultimatum nogeens aangedring op arbitrasie om oorlog te vermy (Bredell \& Grobler, 1947:150, 168). Milner het egter die Britse Regering mislei deur voor te gee dat pres. Kruger besig was om te bluf en sou toegee.

In Maart 1900 toe die prestige van die Republieke in Europa hoog was, het die twee regerings A. Fischer, A.D.W. Wolmarans en C.H. Wessels afgevaardig om "Europese tussenkoms te verkry". Jimmy Smith, 'n Amerikaanse skoolseun van Philadelphia, die eerste stad wat in die 
Amerikaanse Vryheidsoorlog bevry is, het ironies genoeg 'n uur voor president Kruger Pretoria verlaat het, namens hulle skoolkinders aan hom 'n Transvaalse vlag oorhandig en hom bemoedig. Die bejaarde pres. Kruger wat nie meer kon perdry nie en gevaar geloop het om gevang te word, is later ook na Europa gestuur om bemiddeling te probeer kry. Toe Kruger in November 1900 in Frankryk aankom, het skares geroep: "Lank lewe Kruger! Arbitrasie!" Die burgemeester van Parys het gesê "as die regerings swyg, die volkere moet praat" en 'n "skeidsreg" bewerkstellig (Bredell \& Grobler, 1947:171 e.v., 181).

Kruger se reise deur Frankryk, Duitsland en Holland was 'n triomftog van stasie tot stasie, maar die Duitse keiser het plotseling van front verander en wou Kruger nie ontvang nie omdat hy op daardie stadium met Engeland vriende was. Daar was ontsaglike openbare simpatie vir die Boeresaak, maar geen Europese regering wou ingryp nie omdat Engeland in daardie tyd as die sterkste moondheid ter see die magsewewig bepaal het. Dit was te veel verwag van Europese diplomate om die Eerste Wêreldoorlog oor die krenking van volkereg teenoor klein onafhanklike Boererepubliekies te laat losbars. Dit moes nog 14 jaar wag vir 'n onbenullige insident in die Balkan om te gebeur. Die Hollandse regering het egter in April 1902 gehelp om vredesonderhandelinge aan die gang te kry (Kestell, s.j:250).

\subsection{Perspektief op die bitter einde}

Ds. J.D. Kestell (s.j:251 e.v., 271-280) was sekretaris van die Vrystaatse regering by die vredesonderhandelinge in Mei 1902. Hy beskryf die ontsaglike tragiek wat hom daar afgespeel het. Generaals Botha en Smuts wou reeds in 1901 oor vrede onderhandel, maar was egter op daardie stadium - tot ergernis van die Vrystaters - vasbeslote om oor te gee (Kruger, 1958:27). Die Britse beleid van verskroeide aarde het veral Oos-Transvaal uitgeput en op die vlak van hongersnood gebring. In die konsentrasiekampe het minstens 20000 vroue en kinders reeds gesterf "en het afgrijselijk vooruitzicht is ontstaan dat, bij voortzetting van den oorlog, ons gansch geslacht op die wijze zal kunnen uitsterven" (Kestell, s.j:277). Baie vroue en kinders het nie meer klere gehad nie. Die Britte het swart huurtroepe teen vlugtende vroue gestuur. Op Vryheid alleen is 56 Boere vermoor en vermink. Die Engelse het gedreig om vaste eiendom van burgers wat voortveg te konfiskeer. Perde het skaars geraak en ongeveer $30 \%$ van die burgers het te voet geveg. Terwyl die Engelse 31400 Afrikaner-krygsgevangenes oorsee aangehou het en die Boeremagte stelselmatig uitgedun is, moes die burgers elke Tommie wat hulle vang, weer loslaat. Smuts het gesê dat die Afrikaners in die Kaapkolonie nie 'n algemene opstand sou loods nie. 
Pres. Steyn het 'n eed geneem om nooit die onafhanklikheid weg te teken nie (Kruger, 1958: 24). Gevolglik het hy, fisies 'n baie siek man, 'n dag voor die vrede geteken is as president bedank en vir mediese sorg vertrek. "Hij was voor mij daar de verpersoonlijking van het heroïeke, dat voor een groot idee alles ten offer kan brengen" (Kestell, s.j:269). De la Rey het gesorg dat De Wet nie van die Botha-Smuts-kamp wegbreek nie.

Een afgevaardigde zeide dat de oorlog met het gebed en het Mauser was begonnen, en ... wat was Gods antwoord op het gebed geweest? - Kunt gij niet zien ... dat de hand Gods tegen ons uitgestrekt is?" (Kestell, s.j:254).

Die bittereinders het een kant in trane gaan worstel om te berus by die wil van God (Pretorius, 1991:297 e.v.). Toe die Republieke oorgee, het die Engelse aanvaar dat hulle daarmee ook die nog min of meer selfregerende swart volkstate in Oos- en Noord-Transvaal geannekseer het. Brittanje sou hierdie swart volkstate in 1910 as aparte "reservate" sonder stemreg in die Unie van Suid-Afrika inlyf.

\section{Die Oorlog in retrospeksie}

\subsection{Etiese norme het die Christen-Afrikaner tot die Oorlog verplig}

As die Wet van God (liefde) die grond van die sedelike bepaal (H.G. Stoker sr.), het die Britte alle Christelik-etiese norme oortree met hulle roekelose aanslag op die lewens van man, vrou en kind soos Agab op Nabot se wingerd (6de gebod), hulle hebsug waarmee hulle vergryp het aan kollektiewe en privaateiendom van Afrikaners (8ste gebod) en die oneerlike politieke tekening van "primitiewe boere" om hulleself te regverdig (9de gebod). Pasifiste ontken die etiese reg van 'n volk om sy godsdiens, vryheid, staat en eiendom teen 'n verdrukker of indringer te verdedig omdat oorlog met "humaniteit" sou bots (Van Wyk, 1984:152). Leopold Scholtz sê in Beeld (8.11.99) dat volgens die internasionale reg wat vir Bosnië en Rwanda gedefineer is, die Britte hulle "wel deeglik aan 'n misdaad teen die mensdom skuldig gemaak het. En dus het die destydse Boere 'n geregverdigde oorlog teen die Britte geveg". Die lang oorlog het sommige "Boere"-vegters wel "moreel" "gekorrupteer" sodat van hulle hulself ook aan oorlogmisdade skuldig gemaak het. Aan die begin was die motief egter nie verowering, vergelding, prestige of verryking nie, maar om hulle reg op volkwees, hulle republieke en selfbeskikking wat hulle van God ontvang het te verdedig. Die burgers in die twee Republieke het (met steun van Afrikaners uit die Kaapkolonie wat - hoewel hulle nie die republikeinse tradisie gedeel het nie - tog die 
aanslag op hulle as Afrikaners gedeel het), hulle reg op politieke en kulturele bestaan verdedig.

Genl. Christiaan de Wet sê die Vryheidsoorlog was onvermydelik omdat

... een man geen man is, als hy zyn goed recht niet verdedigt. Wy waren ook overtuigd dat het Afrikaansche volk, hoewel het byna bandeloos is ten aanzien van het gebrek aan discipline in oorlogstyd, toch een volk was in welk het onafhankelyksidee zich diep geworteld had (De Wet 1902: 82).

Geen "regering met enige selfrespek" kan hom "sonder teenweer" neerlê as sy volk se onafhanklikheid bedreig word nie (Kruger 1961:235 e.v.). Soos hierbo aangetoon, het die deursnee-Christen-Afrikaner geglo dat God hom verplig om reg te handhaaf, al kos dit wat. D.W. Kruger (1961:233) sê van die Oorlog in 1881: "Die militêr swakkere het oor die moreel swakkere geseëvier". In 1902 het die militêr sterkere oor die moreel sterkere geseëvier.

\subsection{Die Oorlog was vir die Republikeinse Afrikaners 'n ramp}

Die Oorlog, "the costliest, longest and bloodiest war since 1815 and one of the most humiliating in British history" (Pakenham, 1991:xv), het Brittanje 20000 lewens en 200 miljoen pond gekos. Die klein Afrikanergemeenskap van ongeveer 300000 mense het egter 7000 man, 28000 vroue en kinders verloor. Daarby is 14000 swart mense, veral dié wat aan Afrikaners lojaal was, dood (Pakenham, 1991:580; 1979:572). Die Britse beleid van "verskroeide aarde" het beboude plase, huise, meubels, veestapels en die ekonomiese infrastruktuur totaal verwoes. Die bittereinders moes met niks en sonder behoorlike kompensasie voor begin. Daar is nog nie intensief gekyk hoe die Oorlog die Afrikanervolk ekonomies, demografies en fisies geknak het nie. Daar is selfs nie objektief ondersoek hoe anders 'n federasie van state in plaas van 'n politieke unie die Afrikaners se toekoms sou beïnvloed het nie. Oorgawe sonder die Oorlog sou waarskynlik die fisiese ramp gekeer het, maar nooit 'n Tweede Afrikaanse Taalbeweging geloods het nie.

Die vrede was vir baie Engelse 'n antiklimaks want "no doubt there was one thing ... that many Empire-minded Englishmen would rather have forgotten: the methods by which the two colonies had been acquired" (Pakenham, 1991:581). Nietemin het die basiese beginsel van imperialisme, die verabsoluteerde Britse staat (koning en vlag), die plek geneem wat die "volk" (vgl. die Republikeinse volksliedere) voor 1902 in die Christen-Afrikaner se politiek gehad het. Voortaan sou politici die kunsmatige politieke eenheid in die Unie van Suid-Afrika nie betwyfel nie. Die identiteit, belange en regte van die verslane Afrikaners en swart volk- 
stamme in "reservate" is aan die unitêre staat ondergeskik gemaak met die leuse ex unitate vires. Al sou Afrikanerpolitici soms in die 20ste eeu nog na die "volk" verwys, sou hulle die politieke spel voortaan speel op die veld van een onverdeelde staat Suid-Afrika - die staatkundige idee waarvoor die Britte tot 1902 geveg het.

\subsection{Sekularisering van Christen-Afrikanerpolitiek}

In die praktiese politiek lui die Oorlog die doodsklok oor die 19de-eeuse religieuse Christen-Afrikaanse perspektief. Binne die raamwerk van hierdie perspektief het die jong volk noord van die Oranjerivier (en selfs in die Kaapkolonie) soos Israel van ouds homself gesien as 'n skepping van God met 'n eie geskiedenis, identiteit, taal en godsdiens. Die absoluutheid wat die Christen-Afrikaner in die 19de eeu in God gestel het, is in 1902 verplaas deur die absoluutheid wat Milner in die staat gestel het. Hoewel geluide uit die 18de eeu nog gemaak is, het die politieke perspektief van Afrikaners drasties gesekulariseer. Godsdiens en politiek, kerk en staat en selfs partypolitiek en kultuur is radikaal geskei. Die Oorlog sluit die era van Christen-Afrikaner (Boere)-volkspolitiek in nou verband met die volksvisie uit die Ou Testament in sy kinderskoene af.

\subsection{Die Britse unitêre staatsidee vervang die Afrikanervolksidee}

Vir die deursnee-Transvaler het die mantel van Kruger op kmdt. genl. Louis Botha geval (Spoelstra, 1953: 325). Hy was voor die Oorlog 'n teëstander van pres. Kruger en kon maklik inval by die opportunistiese genl. Smuts, 'n Kaapkolonialer wat nie die republikeinse tradisie met moedersmelk ingedrink het. Smuts was na die Oorlog besiel met 'n holistiese visie van een blanke Suid-Afrikaanse staat onder die Britse vlag (Kruger 1958:23 e.v.). In so 'n staat sou die "blanke europeaan" of "Caucasiër" die plek van die Britse kolonialis sou neem en oor die "naturel" gesag voer (Reitz, 1916?: 3, 64). Op hierdie wyse word wegbeweeg van Kruger wat "burgers" en "volk" van "kafferstamme" in meervoud en van "uitlanders" en "vreemdelinge" sonder 'n rassekonnotasie onderskei het (Du Plessis, 1925:24). In die unitêre Kaapkolonie as Britse staat is reeds op rassegrondslag onderskei tussen "european" (veroweraar) en "native" of "non-european" (verowerde). Daar was die begrip "volk" nie praktiese politiek nie. Op sterkte van sending en Westerse "beskawing" is gediskrimineer teen die "natives" in die Kaapkolonie en gevolglik in die Unie van Suid-Afrika (soos elders in die koloniale wêreld) (Spoelstra, 1972:159 e.v.; 1999:3-10, 294-296). Die Land Tenure Act van 1913 bepaal grondbesit nie op etniese nie maar op rassegronde. Waar presidente Kruger en Steyn voor die Oorlog gedink het aan eenheid met Britse kolonies in 'n federasie of konfederasie om die "onaf- 
hanklikheid" van die "volk" (republieke) te bewaar (Du Plessis 1952:31, 82), wou Botha en Smuts "blankes" binne een absolute staat in een verenigde Suid-Afrikaanse Party (SAP) saamsnoer. So het hulle ondersteuners in 1905 dan ook hulle eerste politieke party nostalgies en amper pateties "Het Volk" noem - asof die volk wat die Oorlog verloor het, in 'n politieke party kon herrys (Spoelstra, 1953:324 e.v., 330 e.v, 347).

Die Vrystaat onder leiding van generaals Hertzog en De Wet en die eertydse pres. Steyn is aanvanklik minder beïnvloed deur die unitêre staatsideolgie en het nog die oog op Afrikanerbelange gehou. Hulle lê klem op volk, taal en onderwys en word sterk gesteun uit Kaapland. Hertzog stig in 1914 die Nasionale Party wat op politieke gebied die Tweede Afrikaanse Taalbeweging op kulturele gebied begelei tot ongeveer 1933. Daarna raak Afrikaners partypolities skerp verdeeld; dog die kunsmatige unitêre staatsidee met rassediskriminasie sonder etniese realiteite het gekom om te bly. Geen opportunistiese party kon meer met en vir die "Afrikaanse volk" die Unie regeer nie.

\subsection{Rasseskeiding in plaas van volkeskeiding binne die unitêre staatskonsep}

$\mathrm{Na}$ die Oorlog het Botha plotseling gepleit dat "alle blanken van SuidAfrika met eensgezindheid" vervul sou word sodat "een natie" uit bittereinders, joiners en "uitlanders" gebore sou word (Volkstem, 27.4.04, 25.5.04, 25.2.05; vgl. Pakenham, 1979: 568).

Wij gaan hier in Zuid-Afrika weer een groot volk maken, een Volk samengeteld uit witmensen, uit allen die dit land tot hun Vaderland gemaakt hebben ... (Volksstem, 1.2.05).

Smuts sluit by dié visie aan: "Ons oude doel was geweest een verenigd Zuid-Afrika te stigten ... Laat ons vergeven en vergeten ..." (Volksstem, 23.2.05; vgl. Kruger 1958:33). Kruger se vertrekpunt was die klein onafhanklike Afrikanervolk wat natuurlik onder God se voorsienigheid ontstaan het - onafhanklik van Brittanje en rondomwonende swart nasies. Botha en Smuts se iedeaal was ideologies, "one nation and one people, and they tried to create it artificially". Die kunsmatige produk van die "statemaking" (volgens imperialistiese resep) was die Unie van SuidAfrika, 'n staat van wit mense wat by sy ontstaan doelbewus die meerderheid swart mense nie verdiskonteer het nie (Kruger, 1958:8, 27, 39 e.v.). Gevolglik het Afrikaners in die 20ste eeu in die partypolitiek in baie opsigte Nkrumah se parodie van soek eers die koninkryk van die politiek (vgl. Coetzee, 1981:17) gevolg. 
Apartheid tussen wit en swart onderdane het bestaan in die Britse kolonies van Natal en die Kaapkolonie. Die anomalie is voortgesit in die verabsoluteerde verenigde staat, die Unie van Suid-Afrika. Die volksbewussyn van die 18de eeu wat as vondeling weggelê is, het in die werk van Eugène Marais, Totius, Leipoldt en Celliers begin treur oor die Tweede Vryheidsoorlog. So ook het hierdie volksbewussyn probeer opstaan in Hertzog se Nasionale Party van 1914 en in die Ossewa-trek van 1938. Dit kon egter nie meer die mas opkom teen die idee van die verabsoluteerde staat nie.

\subsection{Imperialisme die kraambed van wyer Afrikanernasionalisme}

Christen-Afrikaners is hoofsaaklik van Nederlandse, Franse-Hugenote en Duitse herkoms - almal state waar vryheid en selfstandigheid van stede en provinsies (state) tot die begin van die 19de eeu swaarder geweeg het as imperiale eenheid. Hulle plattelandse en selfs geïsoleerde bestaan vir geslagte op selfonderhoudende plase het waardering vir die eie, 'n sin vir onafhanklikheid en vryheid teenoor die vreemde gekweek. Afrikaners is dikwels verguis vir hulle endemiese pluriformiteit en individualisme in kerklike en politieke organisasie. Die nadruk op individuele en plaaslike vryheid en verantwoordelikheid was 'n erfenis uit die gereformeerde en Lutherse godsdienste (Spoelstra, 1963:21; 1980:312; 1977; Loots, 1962).

Die druk van buite het 'n dieperliggende eie Afrikaanse nasionalisme en vaderlandsliefde opgebou. "Though they did not know it at the time, the British were shaping a nation" (De Klerk, 1988:67, 96). Imperialisme vir wie die monarg en vlag absolute norm was, het gebots teen hierdie sin vir die eie in die 20ste eeu. Die "volk" het selfs ekonomiese ondernemings soos Volkskas en Sanlam geloods en deur 'n politieke alliansie met die Arbeiderparty van Creswell die Afrikaanse Taal, 'n eie volkslied en vlag op die wetboek geplaas. Hierdie nasionalisme wat uit die neerlaag van die Tweede Vryheidsoorlog opgestaan het, het ingrypend verskil van die messiaanse nasionalisme wat onder leiding van intellektuele leiers soos D.F. Malan na 1933 na vore tree (De Klerk, 1988:hfst. $9,10)$.

\subsection{Morele standaarde van die Afrikaners in die Oorlog het erkenning verdien}

Emily Hobhouse het in haar toespraak wat by die inwyding van die Vrouemonument in Bloemfontein voorgelees is, nie van "Boere" gepraat nie toe sy gesê het "dat julle, die Afrikaners kan bekostig om te vergewe, want op die stuk van sake is dit karakter wat tel" (Coetzee, 1999:23). Sy het veral die "karakter" en inbors van Afrikanervroue en -kinders geken 
wat gevorm is deur gereformeerde godsdiens wat hulle baie meer daagliks en persoonlik as in kerklike gewaad beoefen het.

Dr. E. Macmillan, moderator van die Presbiteriaanse Kerk het in November 1938, kort voor die hoeksteenlegging van die Voortrekkermonument voor 'n deurlugtige gehoor gesê:

We English-speaking South Africans must take the responsibility for our share in keeping the races apart by our refusal to be utterly identified with South Africa, its soil, its language, and its people ... There has been race superiority and pride, that has made us seem selfsufficient ... We cannot hope to be included unless we are at one with the Afrikaner in his effort to rise to a sense of national destiny ... In paying honour to his forefathers the Afrikaner is acknowledging the fact that South Africa's greatest boon is not gold but good character, not material but spiritual values. There is much that we have to repent on both sides ... Especially for us Englishspeaking South Africans. We have not been sensitive. We have been selfish, superior and suspicious. We have been part of the disease rather than part of the cure ... For our deepest failure is moral and spiritual (McCord, 1952:5 h.a. Rand Daily Mail, 28.11.38).

\subsection{Die oorwinning van "Britishism" oor onafhanklikheid het Suid- Afrika verlam}

Die Tweede Vryheidsoorlog was soos dié van die Amerikaners 'n "struggle to create and maintain the environment in which the great South African experiment in liberty could exist and flourish". Die afloop van die Oorlog het die ontwikkeling van die 19de eeu gewelddadig versteur en in ander bane gestuur. So het 'n stryd tussen Britishism en South Africanism - selfs onder Engelssprekendes - tot 1961 gewoed. "Had America not had a successful War of Independence she would now have been in the same position as South Africa" (McCord, 1952:8, 17-19, 29-30, 43).

\section{Bronnelys}

BOSMAN, I.D. s.j. Die Groot Trek 1838-1854. (In Van der Walt, A.J.H., Wiid, J.A. \& Geyer, A.L. Geskiedenis van Suid-Afrika. Verwerk deur D.W. Kruger, 2de druk. : Nasou.

BREDELL, H.C., GROBLER, P. 1947. Gedenkskrifte van Paul Kruger. Vertaal deur Jeanette M. Lange. Pretoria : Van Schaik.

BREYTENBACH, J.H., red. et al. 1949. Gedenkalbum van die Tweede Vryheidsoorlog. Kaapstad: Nasionale Pers.

COETZEE, J.H. 1981. Bittereinders, hensoppers en/of Voortrekkers. Potchefstroom : PU vir CHO. IBC Reeks F1, Nr. 164:1-31.

COETZEE, Therésa. 1999. Op kommando met drie skrywers. Rooi Rose: Maart 3. 
DE KLERK, W.A. 1988. The Puritans in Africa. A story of Afrikanerdom. Durban : Bok Books International.

DE WET, C.R. 1902. De stryd tusschen Boer en Brit. Pretoria : Höveker \& Wormser.

DU PLESSIS, J.S. 1952. President Kruger aan die woord. Verkiesingsmanifeste, intreeredes en toesprake van president S.J.P. Kruger. Bloemfontein : Sacum.

FENSHAM, F.C. 1984. Die Christen-Afrikaner in die twintigste eeu. Potchefstroom : PU vir CHO. IBC Reeks F1, Nr. 202.

FOWLER, H.W. et al. 1944. The Consice Oxford Dictionary of current English. Oxford : Clarendon Press.

HOBHOUSE, E. 1943. Die smarte van die Oorlog en wie dit gely het (1903). Vertaling deur N.J. van der Merwe. Kaapstad : Nasionale Pers.

HOGEWEG, C.P. 1959. Machiavelli. Christelijke Encyclopedie. Kampen : Kok.

KANDYBA-FOXCROFT, Elisaveta. 1981. Russia and the Anglo-Boer War 18991902. Roodepoort : CUM Books.

KESTELL, J.D. s.j. Met de Boeren-commando's. Amsterdam-Pretoria : Höveker \& Wormser.

KNORR, K.E. 1968. British colonial theories 1570-1850. Toronto : University of Toronto Press.

KRUGER, D.W. 1958. The age of the generals. Johannesburg : Dagbreek Book Store.

KRUGER, D.W. 1961. Paul Kruger. Deel I, 1825-1883. Johannesburg : DagbreekBoekhandel.

KRUGER, D.W. 1963. Paul Kruger. Deel II, 1883-1904. Johannesburg : DagbreekBoekhandel.

LOOTS, P.J. 1962. Pluralisme in kerk en staat. Kaapstad : Universiteit van Kaapstad. (Proefskrif.)

McCORD, J.J. 1952. South African struggle. Pretoria : De Bussy.

MOLL, J.C. 1981. Roux, Paul Hendrik. (Suid-Afrikaanse Biogafiese Woordeboek IV.) Pretoria : RGN.

NATHAN, M. 1944. Paul Kruger. His life and times. Durban : Knox.

NEILL, Stephen. 1966. Colonialism and Christian missions. London : Lutterworth.

NGB: Nederlandse Geloofsbelydenis van 1561.

OOST, H. 1956? Wie is die skuldiges? Johannesburg : Afrikaanse Pers Boekhandel.

PAKENHAM, T. 1979. The Boer War. Johannesburg : Jonathan Ball.

PAKENHAM, T. 1991. The scramble for Africa. Johannesburg : Jonathan Ball.

PRETORIUS, Fransjohan. 1991. Kommandolewe tydens die Anglo-Boereoorlog 1899-1902. Kaapstad : Human \& Rousseau.

REITZ, F.W. 1916?. Een eeuw van onrecht. Bloemfontein : Het Volksblad-drukkery.

REITZ, F.W. 1939. 'n Eeu van onreg. Uitgegee op las van die Staatsekretaris van die Suid-Afrikaanse Republiek 1899. Afrikaanse vertaling deur J.J. Blom. Bloemfontein : Nasionale Pers.

SCHUMACHER, G.F. 1973. Small is beautiful; a study of economics as if people mattered. London : Blond \& Briggs.

SPOELSTRA, B. 1953. Die bewindsaanvaarding van die Botha-regering oor Transvaal as selfregerende Britse Kolonie in 1907. (Argief-jaarboek vir SuidAfrikaanse geskiedenis. Deel II: 307-388.) Pretoria : Staatsdrukker.

SPOELSTRA, B. 1963. Die Doppers in Suid-Afrika 1760-1899. Kaapstad : Nasionale Pers.

SPOELSTRA, B. 1972. Kolonialisme en ons sendingkrisis gedurende die vorige eeu. (In Floor, L., red. Die saailand is die wêreld. Hammanskraal : Teologiese Skool. p. 151-192.) 
SPOELSTRA, B. 1977. Die Calvinis se antwoord op meerderheidsregering. Potchefstroom : ACB-kongresreferaat.

SPOELSTRA, B. 1980: Die beginsel in Art. 30 KO. In die Skriflig, 14(55):3-12.

SPOELSTRA, B. 1982. Kan Geloftedag oorlewe? Potchefstroom : IRS. (Studiestuk nr. 180:1-33.)

SPOELSTRA, B. 1999. Sending vir kerk of koninkryk? Sendinggeskiedenis van die GKSA 1869-1994. Potchefstroom : Potchefstroomse Teologiese Publikasies.

TRUTER, Elbie. 1997. Tibbie. Rachel Isabella Steyn, 1865-1955. Kaapstad : Human \& Rousseau.

VAN DER WALT, N.G.S. 1969. Die Republikeinse strewe. Potchefstroom : Pro Rege Pers. (D.Phil.-proefskrif posthuum.)

VAN DER WATT, P.B. 1977. Gemeentes - en nogmaals gemeentes. Pretoria : N.G. Kerkboekhandel.

VAN NIEKERK, Dolf. 1998. Brandoffer. Kaapstad : Human \& Rousseau.

VAN WYK, J.H. 1984. Etiek van vrede. 'n Teologiese evaluering van die Christenpasifisme. Stellenbosch : Cabo.

WARREN, Max. 1967. Social history and Christian mission. London : .

\section{Kernbegrippe:}

Anglo-Boereoorlog

Christen-Afrikaner

oorlog en vrede

Tweede Vryheidsoorlog

\section{Key concepts:}

Anglo Boer War

Christian Afrikaner

Second Liberation War

war and peace 